Article

\title{
Bioreductive Dissolution as a Pretreatment for Recalcitrant Rare-Earth Phosphate Minerals Associated with Lateritic Ores
}

\author{
Ivan Nancucheo ${ }^{1, * \mathbb{D}}$, Guilherme Oliveira ${ }^{2}$, Manoel Lopes ${ }^{2}$ and David Barrie Johnson ${ }^{3}$ \\ 1 Facultad de Ingeniería y Tecnología, Universidad San Sebastián, Lientur 1457, Concepción 4080871, Chile \\ 2 Instituto Tecnológico Vale, Rua Boaventura da Silva 955, Belém, Pará 66055-090, Brazil; \\ Guilherme.Oliveira@itv.org (G.O.); manoeljpl@gmail.com (M.L.) \\ 3 School of Natural Sciences, Bangor University, Deiniol Road, Bangor LL57 2UW, UK; \\ d.b.johnson@bangor.ac.uk \\ * Correspondence: inancucheo@gmail.com; Tel.: +56-(41)-2487433
}

Received: 18 January 2019; Accepted: 21 February 2019; Published: 26 February 2019

\begin{abstract}
Recent research has demonstrated the applicability of a biotechnological approach for extracting base metals using acidophilic bacteria that catalyze the reductive dissolution of ferric iron oxides from oxidized ores, using elemental sulfur as an electron donor. In Brazil, lateritic deposits are frequently associated with phosphate minerals such as monazite, which is one of the most abundant rare-earth phosphate minerals. Given the fact that monazite is highly refractory, rare earth elements (REE) extraction is very difficult to achieve and conventionally involves digesting with concentrated sodium hydroxide and/or sulfuric acid at high temperatures; therefore, it has not been considered as a potential resource. This study aimed to determine the effect of the bioreductive dissolution of ferric iron minerals associated with monazite using Acidithiobacillus (A.) species in $\mathrm{pH}$ - and temperature-controlled stirred reactors. Under aerobic conditions, using $A$. thiooxidans at extremely low $\mathrm{pH}$ greatly enhanced the solubilization of iron from ferric iron minerals, as well that of phosphate (about 35\%), which can be used as an indicator of the dissolution of monazite. The results from this study have demonstrated the potential of using bioreductive mineral dissolution, which can be applied as pretreatment to remove coverings of ferric iron minerals in a process analogous to the bio-oxidation of refractory golds and expand the range of minerals that could be processed using this approach.
\end{abstract}

Keywords: iron reduction; reductive mineral dissolution; Acidithiobacillus; laterites; phosphate mineral; REE

\section{Introduction}

Currently the main supplier of REE to the world market is China, which accounted for $86 \%$ of total world production in 2014 and hosts the largest ( $42 \%)$ proportion of the total global reserves, estimated to be ca. 110 million tons [1,2]. The demand for REE is growing at a rate of approximately $5-10 \%$ as these metals are increasingly used in modern technology including the metallurgy, fine chemical, automotive, oil, and renewable energies industries, etc. [3,4]. In recent years, there has been an increasing effort to identify additional potential supplies of REE to limit economic risk in the supply chain, given the fact that cuts in China's exports quota in recent years have provoked uncertainty among the hi-tech markets [4]. The three main rare-earth-bearing minerals are monazite, bastnaesite, and xenotime; these are highly refractory minerals and are not solubilized by conventional chemical treatment, requiring digestion with sulfuric acid and/or concentrated sodium hydroxide at high temperatures $[5,6]$. 
Biomining is now well established as an important applied biotechnology in the metal mining sector; it is often perceived as a technology that is less energy consuming and has also been promoted as being a more "environmentally friendly" approach to processing minerals ores and concentrates than conventional practices such as smelting. Biomining operations use far lower temperatures and pressures than conventional extraction processes, require less energy, and produce lower $\mathrm{CO}_{2}$ emissions, though extraction of metals from primary ores and wastes tend to be far more protracted [7]. Although current commercial-scale biomining operations use the ability of acidophilic microorganisms to extract metals exclusively from reduced (sulfidic) ores, it has also been shown that bioreductive mineral dissolution can be used to process iron oxide ores to facilitate the recovery of metals [8-10]. Some acidophilic prokaryotes can catalyze the dissimilatory reduction of ferric iron; these include several species of Acidithiobacillus, which are better known for their ability to catalyze the oxidative dissolution of metal sulfide minerals. A. ferrooxidans was shown to couple the oxidation of sulfur to the reduction of ferric iron present in the mineral phase, facilitating the recovery of valuable metals [8]. In addition, it has been well established that heterotrophic acidophilic bacteria also catalyzed dissimilatory ferric iron reduction from ferric iron mineral (i.e., schwertmannite) using organic compounds as the electron donor and carbon source [11].

Many valuable metals occur in nature in oxidized ores and are therefore not amenable to oxidative bioprocessing. There are some reports of solubilization of metals from low-grade lateritic ores using organic acids produced by heterotrophic fungi, though sometimes poor efficiency in metal recovery, high costs of microbial substrates, and the issue of biomass disposal are reasons why this approach has not been exploited commercially [8,12]. Using acidophilic bacteria to enhance the recovery of nickel from laterites was found to be more cost effective in low-pH liquors (where cationic transition metals are far more soluble) and ambient temperatures. Under anaerobic conditions and using a $\mathrm{pH}$ and temperature-controlled bioreactor ( $\mathrm{pH} 1.8$ and $30^{\circ} \mathrm{C}$ ), A. ferrooxidans was found to be effective in recovering both nickel (mostly associated with iron oxide phases, such as goethite) and cobalt (mostly associated with manganese oxide minerals, such as asbolane) from limonitic laterite [13]. Elsewhere, oxidized mineral waste from a copper mine from Brazil that contained $0.8 \%$ copper was subjected to reductive dissolution using pure and mixed cultures of iron-reducing acidophiles [14]. This study evaluated different operating parameters to increase copper recovery; bacterial numbers, in particular, were noted to have a critical role in copper extraction. More recently, Acidithiobacillus spp. were reported to extract cobalt (50\%) and nickel (70\%) from nickel laterite tailings within 7 days under aerobic conditions at extremely low $\mathrm{pH}$ ( $\mathrm{pH} 0.8 ;[10])$. Furthermore, this process was used to leach a laterite overburden in an aerobic bioreactor maintained at $\mathrm{pH} 0.8$ [15]. The major ionic form of iron in this case was ferric iron, which was released from the tailings by the sulfuric acid generated by A. thiooxidans, which is more tolerant of extreme acidity than the iron-oxidizing acidithiobacilli [16].

Lateritic deposits that contain phosphate minerals with high grades of REE are important resources found in Brazil (in average $8 \%$ in Goias state; [17]), where monazite is one of the most abundant rare-earth phosphate minerals. Catalão, State of Goiás is reported to have 120 million tons of ore, confirming that is one of the countries with the largest reserves of valuable light REE (mainly La and Ce). So far, this material has not been studied using this radical approach in mineral bioprocessing and also not considered as an important source of recovered REE. We have tested the hypothesis that reductive dissolution of these deposits by Acidithiobacillus species, maintained under both aerobic and anaerobic conditions and at between $\mathrm{pH} 0.9$ and 1.8, could mediate the dissolution of ferric iron minerals and facilitate the further processing of monazite.

\section{Materials and Methods}

\subsection{Characteristics of the Ore}

The lateritic ore containing monazite was sourced from a phosphate mine in Brazil and subjected to beneficiation. Mineralogical analysis showed that monazite was the main phosphate ore ( 90\%), 
and the major iron phases consisted mainly of goethite ( $60 \%)$ together with magnetite and hematite. The material contained 6.9\% REE, $42 \% \mathrm{Fe}_{2} \mathrm{O}_{3}, 12 \% \mathrm{SiO}_{2}, 8.1 \% \mathrm{P}_{2} \mathrm{O}_{5}, 7 \% \mathrm{TiO}_{2}$, and $6.5 \% \mathrm{Al}_{2} \mathrm{O}_{3}$ as the major oxides. Mineralogical and chemical composition analyses of the laterite were carried out as described elsewhere [14]. All tests were performed with monazite-containing lateritic material which was ground and sieved to below $1 \mathrm{~mm}$ particle size. Table 1 shows the elemental composition of the lateritic material.

Table 1. Chemical composition of elements of the laterite ore evaluated in this study.

\begin{tabular}{ccccccc}
\hline Element & Fe & P & Ce & La & U & Th \\
\hline Concentration $(\mathrm{g} / \mathrm{kg})$ & 301 & 34.9 & 27 & 13.2 & 0.088 & 0.401 \\
\hline
\end{tabular}

\subsection{Bacteria and Cultivation Conditions}

The mesophilic acidophiles $A$. ferrooxidans (ATCC $23270^{\mathrm{T}}$ ) and $A$. thiooxidans (DSM 14557 ${ }^{\mathrm{T}}$ ) were used in this study. Bacteria were grown in shake flasks containing $200 \mathrm{~mL}$ of liquid medium, comprising basal salts with trace elements [18] and $1 \mathrm{~g}$ of elemental sulfur. Cultures were incubated at $30^{\circ} \mathrm{C}$ and an initial $\mathrm{pH}$ of 3.0 before being used as inocula for the bioreactor experiments.

\subsection{Reductive Mineral Dissolution under Anaerobic Conditions}

The iron-oxidizing/-reducing acidophile A. ferrooxidans was used in these experiments. Prior to inoculation, two stirred bioreactors, each with $2 \mathrm{~L}$ working volumes and fitted with $\mathrm{pH}$, temperature, and aeration control (Electrolab, UK), were set up. Fifty grams of elemental sulfur and $1.95 \mathrm{~L}$ of basal salts and trace elements [18] adjusted to $\mathrm{pH} 1.8$ were put into each reactor vessel, which were then autoclaved at $110{ }^{\circ} \mathrm{C}$ for $40 \mathrm{~min}$ [14]. Once cooled, each bioreactor was inoculated with $50 \mathrm{~mL}$ of A. ferrooxidans culture grown on sulfur. The bioreactors were maintained at $30^{\circ} \mathrm{C}$ and a constant $\mathrm{pH}$ of 1.8 , stirred at $150 \mathrm{rpm}$, and aerated at $1 \mathrm{~L} / \mathrm{min}$ with sterile atmospheric air. When numbers of planktonic cells had reached $\sim 10^{9} / \mathrm{mL}$ (enumerated using a Thoma counting chamber), the air supply to one of them was removed and replaced with oxygen-free nitrogen (OFN) to promote anaerobic conditions while the second bioreactor was maintained with $\mathrm{OFN}$ enriched with $10 \% \mathrm{CO}_{2}$. Twenty-five grams of lateritic ore were then added to each of the bioreactors. To assess whether the dissolution of the lateritic ore was catalyzed by the bacteria, a third non-inoculated reactor with basal salts and trace elements was operated abiotically by gassing with OFN at $\mathrm{pH} 1.8$ (by the addition of $0.5 \mathrm{M}$ sulfuric acid) and $30{ }^{\circ} \mathrm{C}$. The bioreactors were operated for up to 30 days and samples were removed at regular intervals for chemical analysis and to determine numbers of viable bacteria by plating on selective solid media [14].

\subsection{Reductive Dissolution under Aerobic Conditions}

Two $2 \mathrm{~L}$ (working volume) bioreactors, each containing $50 \mathrm{~g}$ of elemental sulfur and $1.95 \mathrm{~L}$ of basal salts and trace elements ( $\mathrm{pH} 1.8)$, were sterilized as described previously and, when cool, inoculated with $A$. thiooxidans. The bioreactors were aerated at $1 \mathrm{~L}$ sterile air/min and stirred at $150 \mathrm{rpm}$. Once the $\mathrm{pH}$ had fallen to either 0.9 (Reactor 1 ) or 1.2 (Reactor 2) as a consequence of biogenic sulfuric acid production, $25 \mathrm{~g}$ of lateritic ore was added to each vessel. Samples were withdrawn as before. As controls, non-inoculated reactors containing lateritic ore and elemental sulfur, together with basal salts and trace elements, were operated at fixed $\mathrm{pH}$ values of 0.9 and 1.2 by the addition of $0.5 \mathrm{M}$ sulfuric acid.

\subsection{Analytical Techniques}

Concentrations of ferrous iron were measured colorimetrically using the Ferrozine assay [19]. Concentrations of total soluble iron were measured using a Dionex ICS-5000 ion chromatography [20] system fitted with an IonPAC CS5A column and an AD25 absorbance detector (Thermo Fisher Scientific 
Inc.). Phosphate concentrations were measured using a Dionex ICS-5000 ion chromatograph fitted with an Ion Pac AS-11 equipped with a conductivity detector [21]. Concentrations of lanthanum, cerium, uranium, and thorium in filtered (through $0.2 \mu \mathrm{m}$ pore-sized polycarbonate filters) mineral leachate samples at the end of the experiments were determined by ICP-MS (NexION 300, PerkinElmer, 2015).

\section{Results}

The concentrations of total soluble iron in the two bioreactors that were operated under anoxic conditions and fixed $\mathrm{pH}(1.8)$ using $A$. ferrooxidans and, the corresponding abiotic control are shown in Figure 1A. The reductive dissolution of ferric iron minerals was greater in the bioreactor that was continuously sparged with the OFN $/ \mathrm{CO}_{2}$ gas mix than that which was sparged only with OFN. In both reactors, virtually all the soluble iron was present as ferrous iron, concentrations of which increased rapidly during the first 10 days of the experiment but slowed down thereafter. Dissolution of the laterite sample also occurred under aerobic conditions catalyzed by $A$. thiooxidans (Figure 1B), and this was more effective at $\mathrm{pH} 0.9$ than at $\mathrm{pH}$ 1.2. Again, this was a reductive process, as most of the soluble iron was present as ferrous iron throughout the experiment. Concentrations of soluble iron increased at a relatively constant rate in the aerobic $\mathrm{pH} 1.2$ bioreactor, whereas a more biphasic pattern was observed at $\mathrm{pH}$ 0.9. The final concentration of soluble iron in the aerobic $\mathrm{pH} 0.9$ bioreactor $(985 \mathrm{mg} / \mathrm{L}) \mathrm{was}$ about twice that in the $\mathrm{pH} 1.8$ anaerobic bioreactor sparged with $\mathrm{OFN} / \mathrm{CO}_{2}(530 \mathrm{mg} / \mathrm{L})$ and $\sim 3$ times greater than that in the $\mathrm{pH} 1.8$ anaerobic bioreactor sparged with OFN (340 mg/L). The greatest extent of total iron minerals extracted from the laterite ore $(\sim 30 \%)$ occurred in the aerobic $\mathrm{pH} 0.9$ bioreactor. In contrast to the inoculated reactors, most of the iron solubilized from the lateritic ore under abiotic conditions (both aerobic and anoxic bioreactors) was present as ferric iron (data not shown), and both the rates and extents of mineral dissolution were much less than when bacteria were present.



(A)

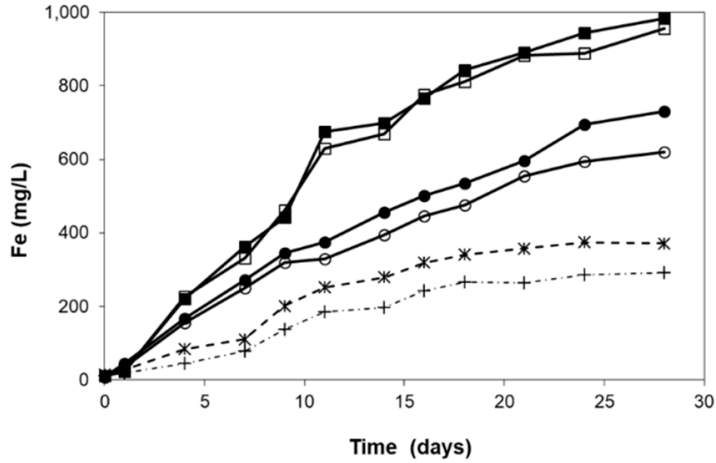

(B)

Figure 1. Total soluble iron (solid symbols) and ferrous iron (hollow symbols) leached from the laterite ore (A) under anoxic conditions using A. ferrooxidans at $\mathrm{pH} 1.8$ and $30^{\circ} \mathrm{C}$, sparged with (i) oxygen-free nitrogen $(\mathrm{OFN})(\diamond, \diamond)$ and (ii) OFN enriched with $10 \%$ of $\mathrm{CO}_{2}(\boldsymbol{\Delta}, \Delta)$. (B) Under aerobic conditions using $A$. thiooxidans at (i) $\mathrm{pH} 0.9(\boldsymbol{\square}, \square)$ and (ii) $\mathrm{pH} 1.2(\bullet, \mathrm{o})$. Dashed lines show the concentrations of total soluble iron in the non-inoculated reactors: anoxic, $\mathrm{pH} 1.8$ (x); aerobic, $\mathrm{pH} 1.2(+)$; aerobic, pH $0.9(\boldsymbol{*})$.

The concentrations of soluble phosphate increased rapidly within the first 2 days of leaching in all reactors (aerobic and anoxic; inoculated and non-inoculated) but solubilization of phosphate minerals slowed down in most cases thereafter (Figure 2). The concentrations of phosphate in both of the inoculated anoxic bioreactors were similar throughout the experiment and were much greater than those in the sterile control (Figure 2A). In the aerobic reactors, more phosphate was both abiotically and microbially leached at $\mathrm{pH} 0.9$ than at $\mathrm{pH} 1.2$, and again, in both cases, the presence of bacteria (A. thiooxidans in this case) greatly enhanced the solubilization of phosphate minerals (Figure 2B). 
The amount of phosphate released from the lateritic ore using $A$. thiooxidans at $\mathrm{pH} 0.9$ was $35 \%$ greater than that by $A$. ferrooxidans sparged continuously with $\mathrm{OFN} / \mathrm{CO}_{2}$ at $\mathrm{pH} 1.8$.

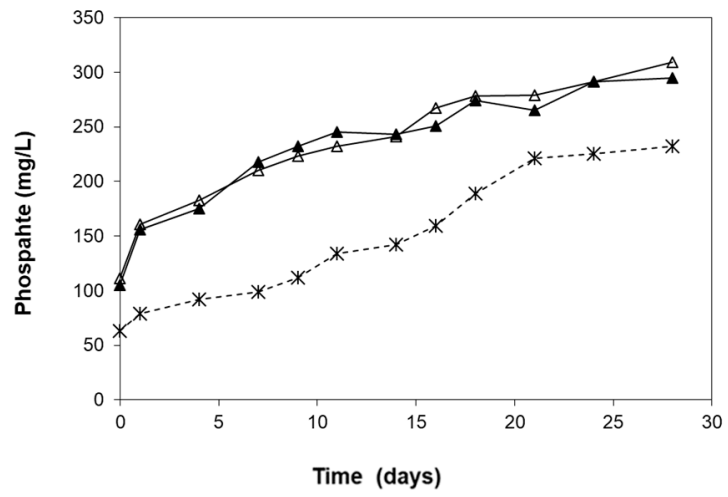

(A)

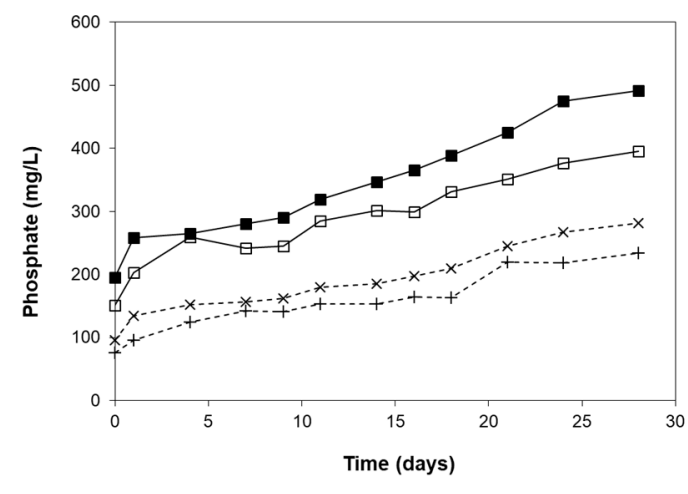

(B)

Figure 2. Solubilization of phosphate in the bioreactors subjected to reductive dissolution (A) under anoxic conditions using $A$. ferrooxidans sparged with (i) OFN (closed triangles) and (ii) OFN enriched with $10 \%$ of $\mathrm{CO}_{2}$ (open triangles). (B) Under aerobic conditions using $A$. thiooxidans at (i) $\mathrm{pH} 0.9$ (closed squares) and (ii) pH 1.2 (open squares). Dashed lines show the solubilization of total iron in the non-inoculated reactors at $\mathrm{pH} 1.8(\boldsymbol{*}), 1.2(+)$, and $0.9(\mathrm{x})$.

Analysis of the laterite leachates at the end of the experiments showed that there were similar concentrations of cerium, lanthanum, and uranium present in all three reactors (inoculated and control) that were operated at pH 1.8 and under anoxic conditions (Figure 3A).

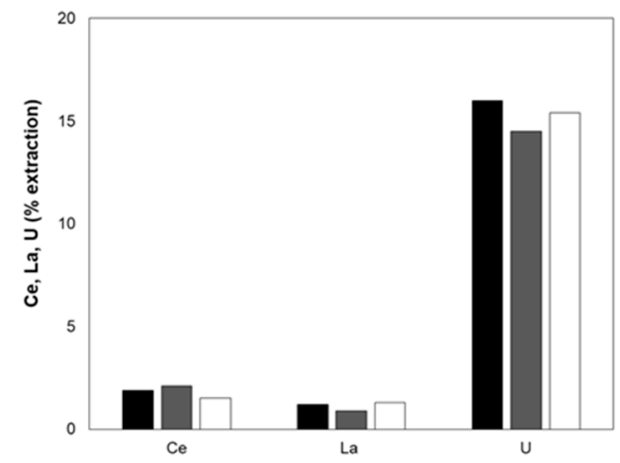

(A)

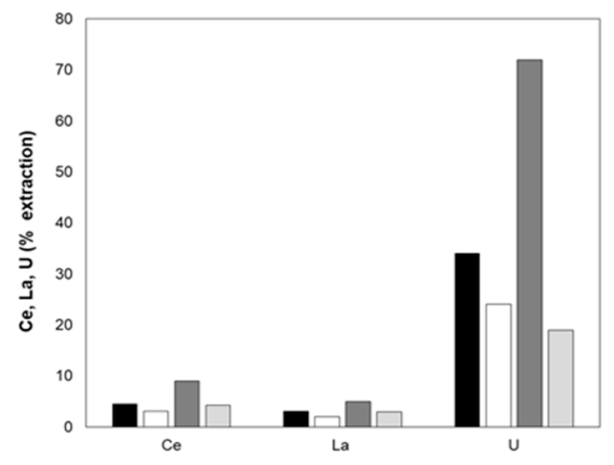

(B)

Figure 3. Percentages of cerium, lanthanum, and uranium extracted from the laterite ore, determined from the concentrations of these metals present in leachates at the end of the experiments. (A) A. ferrooxidans at $\mathrm{pH} 1.8$, sparged with OFN (black bars) or with $\mathrm{OFN} / \mathrm{CO}_{2}$ (dark grey bars) and the corresponding abiotic control (white bars); (B) A. thiooxidans at pH 1.2 (black bars) and the corresponding abiotic control (white bars), and at $\mathrm{pH} 0.9$ (dark grey bars) and the corresponding abiotic control (light grey bars). Note: the axis scales show the differences obtained under the anoxic and aerobic conditions using Acidithiobacillus species.

In contrast, the concentrations of all three metals were greater in the bioreactors that were inoculated with $A$. thiooxidans than in the corresponding abiotic controls, particularly at $\mathrm{pH} 0.9$ (Figure 3B). Thorium levels were also determined, and the amount extracted in all three reactors even at $\mathrm{pH} 0.9$ showed similar concentrations ( 4\%; data not shown).

Although the numbers of total viable planktonic bacteria decreased in all bioreactors during the course of these experiments, the extents to which this occurred were different in the four inoculated reactors (Figure 4). The numbers of planktonic A. ferrooxidans grown under anoxic conditions and 
gassed with $\mathrm{OFN} / \mathrm{CO}_{2}$ remained fairly constant throughout the experiment. More pronounced was the decline in numbers of $A$. thiooxidans in both aerobic bioreactors, though it is worth mentioning that most of the solubilization of iron occurred during the first 15 days of operation $(\sim 80 \%)$.

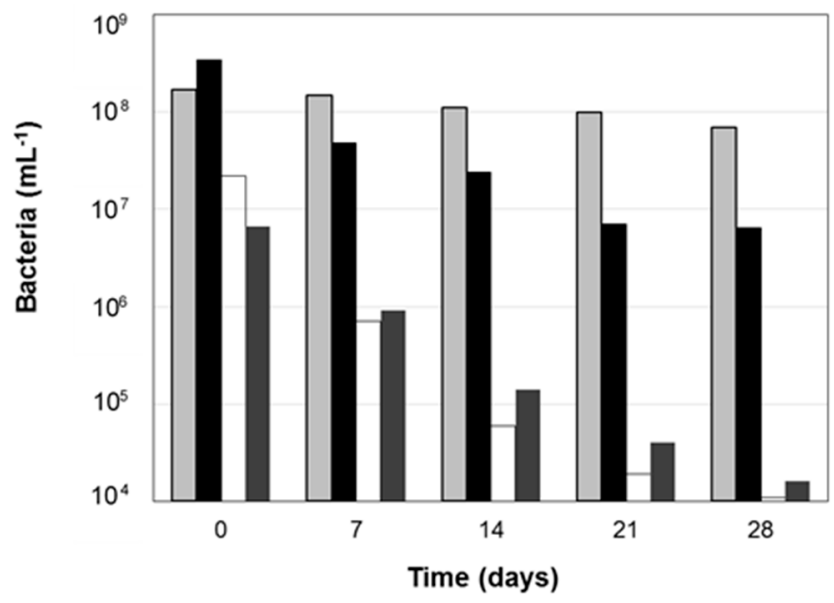

Figure 4. Changes in numbers of viable acidophilic bacteria in the bioreactors: A. ferrooxidans sparged with OFN (black bars) or OFN/ $\mathrm{CO}_{2}$ (light grey bars); A. thiooxidans $\mathrm{pH} 0.9$ (white bars) and 1.2 (dark grey bars).

\section{Discussion}

The reductive dissolution of limonitic laterite ores represents a radical development in mineral bioprocessing and contrasts with conventional biomining operations where bioleaching of metal-containing sulfide minerals or the bio-oxidation of refractory gold ores is mediated by microbially catalyzed oxidative dissolution [22]. As the supply of REEs is crucial for many developed countries, it is becoming increasingly necessary to seek new technologies that are more environmentally benign than the existing approaches used to facilitate the processing of REE-bearing ores. The abundance of lateritic ores, particularly in tropical areas, represents an important source of polymetallic metals including nickel, cobalt, manganese, and copper, which have previously been proven amenable to bioreductive dissolution $[8,10,14,23]$. The results from this work show that the reductive bioprocessing of ferric iron minerals in lateritic ores containing monazite using acidophilic microorganisms can be partially effective in enhancing the solubilization of phosphate minerals that contain REE.

While the percentage of iron leached from the material was relatively small $(<30 \%)$, this may be perceived as an advantage as the ferrous-iron-rich process liquors produced would require less intensive downstream mitigation [23]. It is worth mentioning that the laterite ore used was rich in goethite but contained no detectable magnesium oxide, therefore delineating it as limonitic [24]. Using $A$. thiooxidans at extremely low $\mathrm{pH}$ greatly enhanced the solubilization of iron from ferric iron minerals, as well that of phosphate, which can be used as indicator of the dissolution of monazite. Acid abiotic leaching experiments were partially effective at solubilizing phosphate from the ore, and this was more effective at very low $(<1) \mathrm{pH}$, but in all cases, reductive bioleaching catalyzed by the acidithiobacilli used was superior in this respect. These results suggest that monazite is intimately associated with ferric iron minerals such as goethite present in the ore, and, therefore, that reductive mineral dissolution can be used to remove surface coverings of ferric iron in a process analogous to the bio-oxidation of refractory golds [9].

In addition, the reductive conditions of this bioprocess can partially facilitate the exposure of monazite to attack by acid leaching from the biogenic sulfuric acid produced by the bacteria, enhancing the phosphate solubilization. In contrast, a chemical acid process is not enough by itself to leach phosphate from the matrix, demonstrated with the experiment carried out under abiotic conditions, which is inferior to reductive dissolution. Although $\sim 9 \%$ of the cerium and $5 \%$ of the lanthanum were leached using $A$. thiooxidans at $\mathrm{pH} 0.9$, the results again suggest that bioreductive dissolution can 
improve accessibility to monazite, but further studies including analysis of the residue are needed. Recent studies addressing only monazite dissolution using phosphate-solubilizing bacteria have shown different degrees of success with leaching efficiencies for REE recovery (between $0.1 \%$ and $25 \%$ ), though differences in ores and experimental conditions may explain the varying results $[5,25,26]$.

The results of these experiments both confirmed some earlier findings regarding the bioprocessing of lateritic ores. Reductive dissolution of the ore was catalyzed by A. ferrooxidans grown at $\mathrm{pH} 1.8$ under anoxic conditions where ferric iron was reduced, and the ferrous iron generated could not be re-oxidized. In addition, aerobic reductive dissolution using bioreactors inoculated with $A$. thiooxidans was previously reported to be effective in recovering nickel from laterite tailings $[10,15]$. The results from this study confirm that dissolution of ferric iron and phosphate minerals was more rapid and extensive at lower $\mathrm{pH}$ values. A. thiooxidans was confirmed to mediate reductive mineral dissolution even in well-aerated reactor vessels, and, since this acidophile cannot oxidize iron, the ferrous iron generated remained in the reduced form. Since most of the soluble iron in the abiotic reactors was present as ferric iron, the inference is that, as suggested elsewhere [8], iron was firstly acid-solubilized from goethite and other oxidized minerals and then reduced biologically to ferrous.

However, other data support the notion that $A$. thiooxidans appeared to die off in these bioreactors (viable cell numbers decreased, especially in the $\mathrm{pH} 0.9$ reactor) and little reduction of ferric iron occurred after 15 days. One reason for this could be that $A$. thiooxidans became less viable because of the very low $\mathrm{pH}$ values at which the bioreactors were maintained, though this acidophile is known to be more tolerant of extreme acidity than the iron-oxidizing acidithiobacilli [16]. These conundrum observations merit further study, though adding sufficient quantities of exogenously grown cultures could be used as a strategy to maintain the desired reactions. While it has long been known that A. thiooxidans can reduce ferric iron [27], later work showed that this acidophile cannot grow by ferric iron respiration [28]. Reduction of ferric iron in aerobically grown cultures has been shown to be widespread amongst the acidithiobacilli [29], and ongoing reduction of soluble ferric iron by Acidithiobacillus caldus has recently been shown to sustain the growth of Leptospirillum ferriphilum in mixed cultures [30]. The fact that ferric iron can be reduced under aerobic conditions extends the potential for the bioprocessing of minerals such as goethite.

\section{Conclusions}

This study provides a proof of concept that bacterially catalyzed reductive dissolution of a lateritic ore can be used to remove sufficient ferric iron minerals to facilitate the dissolution of monazite. The process was more effective when carried out at ultra-low $(<1)$ than at higher $\mathrm{pH}$ values, where it was mediated by $A$. thiooxidans maintained under aerobic conditions. In addition, the results obtained suggest that reductive dissolution can improve the exposure of monazite to the acidic conditions, though further studies are needed since this approach is a relatively new area of biohydrometallurgy.

Author Contributions: Conceptualization and methodology, I.N.; investigation, I.N., G.O. and M.L.; resources, I.N. and G.O.; writing - original draft preparation, I.N., G.O. and D.B.J.; writing-review and editing, I.N. and D.B.J.; funding acquisition, I.N. and G.O.

Funding: The authors acknowledge the financial support from Conselho Nacional de Desenvolvimento Científico e Tecnológico (CNPq-309312/2012-4) of Guilherme Oliveira and Vale (BioDam). Ivan Nancucheo is supported by Fondecyt, Chile ( $\left.\mathrm{n}^{\circ} 11150170\right)$.

Conflicts of Interest: The authors declare no conflict of interest.

\section{References}

1. Fan, H.R.; Yang, K.F.; Hu, F.F.; Liu, S.; Wang, K.Y. The giant Bayan Obo REE-Nb-Fe deposit, China: Controversy and ore genesis. Geosci. Front. 2016, 7, 335-344. [CrossRef]

2. Wübbeke, J. Rare earth elements in China: Policies and narratives of reinventing an industry. Resour. Policy 2013, 38, 1-11. [CrossRef] 
3. Pourret, O.; Tuduri, J. Continental shelves as potential resource of rare earth elements. Sci. Rep. 2017, 7, 1-6. [CrossRef] [PubMed]

4. Massari, S.; Ruberti, M. Rare earth elements as critical raw materials: Focus on international markets and future strategies. Resour. Policy 2013, 38, 36-43. [CrossRef]

5. Shin, D.; Kim, J.; Kim, B.; Jeong, J.; Lee, J. Use of phosphate solubilizing bacteria to leach rare earth elements from monazite-bearing Ore. Minerals 2015, 5, 189-202. [CrossRef]

6. Maes, S.; Zhuang, W.Q.; Rabaey, K.; Alvarez-Cohen, L.; Hennebel, T. Concomitant leaching and electrochemical extraction of rare rarth elements from monazite. Environ. Sci. Technol. 2017, 51, 1654-1661. [CrossRef] [PubMed]

7. Johnson, D.B. Biomining-biotechnologies for extracting and recovering metals from ores and waste materials. Curr. Opin. Biotechnol. 2014, 30, 24-31. [CrossRef] [PubMed]

8. Hallberg, K.B.; Grail, B.M.; Plessis, C.A.D.; Johnson, D.B. Reductive dissolution of ferric iron minerals: A new approach for bio-processing nickel laterites. Miner. Eng. 2011, 24, 620-624. [CrossRef]

9. Johnson, D.B.; Du Plessis, C.A. Biomining in reverse gear: Using bacteria to extract metals from oxidised ores. Miner. Eng. 2015, 75, 2-5. [CrossRef]

10. Marrero, J.; Coto, O.; Goldmann, S.; Graupner, T.; Schippers, A. Recovery of nickel and cobalt from laterite tailings by reductive dissolution under aerobic conditions using Acidithiobacillus species. Environ. Sci. Technol. 2015, 49, 6674-6682. [CrossRef] [PubMed]

11. Coupland, K.; Johnson, D.B. Evidence that the potential for dissimilatory ferric iron reduction is widespread among acidophilic heterotrophic bacteria. FEMS Microbiol. Lett. 2008, 279, 30-35. [CrossRef] [PubMed]

12. Mulligan, C.N.; Kamali, M. Bioleaching of copper and other metals from low-grade oxidized mining ores by Aspergillus niger. J. Chem. Technol. Biotechnol. 2003, 78, 497-503. [CrossRef]

13. Johnson, D.B.; Grail, B.M.; Hallberg, K.B. A new direction for biomining: Extraction of metals by reductive dissolution of oxidized ores. Minerals 2013, 3, 49-58. [CrossRef]

14. Nancucheo, I.; Grail, B.M.; Hilario, F.; Du Plessis, C.; Johnson, D.B. Extraction of copper from an oxidized (lateritic) ore using bacterially catalysed reductive dissolution. Appl. Microbiol. Biotechnol. 2014, 98, 6297-6305. [CrossRef] [PubMed]

15. Marrero, J.; Coto, O.; Schippers, A. Anaerobic and aerobic reductive dissolutions of iron-rich nickel laterite overburden by Acidithiobacillus. Hydrometallurgy 2017, 168, 49-55. [CrossRef]

16. Dopson, M. Physiological and phylogenetic diversity of acidophilic bacteria. In Acidophiles: Life in Extremely Acidic Environments; Quatrini, R., Johnson, D.B., Eds.; Caistor Academic Press: Haverhill, UK, 2016; pp. 79-92.

17. Tassinari, M.M.L.; Kahn, H.; Ratti, G. Process mineralogy studies of Corrego do Garimpo REE ore, Catalao-I Alkaline complex, Goias, Brazil. Miner. Eng. 2001, 14, 1609-1617. [CrossRef]

18. Nancucheo, I.; Rowe, O.F.; Hedrich, S.; Johnson, D.B. Solid and liquid media for isolating and cultivating acidophilic and acid-tolerant sulfate-reducing bacteria. FEMS Microbiol. Lett. 2016, 363, 1-6. [CrossRef] [PubMed]

19. Stookey, L.L. Ferrozine-A new spectrophotometric reagent for iron. Anal. Chem. 1970, 42, 779-781. [CrossRef]

20. Nancucheo, I.; Johnson, D.B. Selective removal of transition metals from acidic mine waters by novel consortia of acidophilic sulfidogenic bacteria. Microb. Biotechnol. 2012, 5, 34-44. [CrossRef] [PubMed]

21. Jenke, D.; Sadain, S.; Nunez, K.; Byrne, F. Performance characteristics of an ion chromatographic method for the quantitation of citrate and phosphate in pharmaceutical solutions. J. Chromatogr. Sci. 2017, 45, 50-56. [CrossRef]

22. Rawlings, D.E.; Johnson, D.B. The microbiology of biomining: Development and optimization of mineral-oxidizing microbial consortia. Microbiology 2007, 153, 315-324. [CrossRef] [PubMed]

23. Smith, S.L.; Grail, B.M.; Johnson, D.B. Reductive bioprocessing of cobalt-bearing limonitic laterites. Miner. Eng. 2017, 106, 86-90. [CrossRef]

24. Komnitsas, K.; Petrakis, E.; Pantelaki, O.; Kritikaki, A. Column Leaching of Greek Low-Grade Limonitic Laterites. Minerals 2018, 8, 377. [CrossRef]

25. Brisson, V.L.; Zhuang, W.Q.; Alvarez-Cohen, L. Bioleaching of rare earth elements from monazite sand. Biotechnol. Bioeng. 2016, 113, 339-348. [CrossRef] [PubMed]

26. Corbett, M.K.; Eksteen, J.J.; Zhi, X.; Jean, N.; Croue, P.; Watkin, E.L.J. Interactions of phosphate solubilising microorganisms with natural rare-earth phosphate minerals: A study utilizing Western Australian monazite. Bioprocess Biosyst. Eng. 2017, 40, 929-942. [CrossRef] [PubMed]

27. Brock, T.D.; Gustafson, J. Ferric iron reduction by sulfur- and iron-oxidizing bacteria. Appl. Environ. Microbiol. 1976, 32, 567-571. [PubMed] 
28. Hallberg, K.B.; Thompson, H.E.C.; Boeselt, I.; Johnson, D.B. Aerobic and anaerobic sulfur metabolism by acidophilic bacteria. In Biohydrometallurgy: Fundamentals, Technology and Sustainable Development; Process Metallurgy 11A; Ciminelli, V.S.T., Garcia, O., Jr., Eds.; Elsevier: Amsterdam, the Netherlands, 2001; pp. $423-431$.

29. Johnson, D.B.; Hedrich, S.; Pakostova, E. Indirect redox transformations of iron, copper, and chromium catalyzed by extremely acidophilic bacteria. Front. Microbiol. 2017, 8, 1-15. [CrossRef] [PubMed]

30. Smith, S.L.; Johnson, D.B. Growth of Leptospirillum ferriphilum in sulfur medium in co-culture with Acidithiobacillus caldus. Extremophiles 2018, 22, 327-333. [CrossRef] [PubMed]

(C) 2019 by the authors. Licensee MDPI, Basel, Switzerland. This article is an open access article distributed under the terms and conditions of the Creative Commons Attribution (CC BY) license (http:/ / creativecommons.org/licenses/by/4.0/). 